\title{
Free radicals and antioxidants in human diseases
}

\author{
J. Pincemail
}

Department of Cardiovascular Surgery, University of Liege, CHU B35, Sart Tilman, B-4000 Liège, Belgium

\begin{abstract}
Summary. Increased free radicals formation derived from abnormal metabolism of oxygen has been implicated in over 100 different human diseases which may be classified into six categories: chemical and xenobiotic toxicity, radiation injury, hyperoxygenation syndromes, inflammatory conditions, postischemic reperfusion injury and degenerative conditions. As their in vivo evidence always remains a difficult challenge, there is, however, a great deal of confusion about their precise role in the development of human diseases. Whatever the precise mechanism, preventing free radical generation by appropriate antioxidant therapy should provide beneficial clinical consequences.
\end{abstract}

\section{Introduction: The "oxygen paradox"}

Oxygen, friend or foe? Oxygen, a poison required for life. Oxygen, a dangerous friend. Oxygen, from Charybdis to Scylla. Oxygen represented as Janus. All these clichés are regularly used in the scientific literature and meetings discussing that oxygen that is so indispensable to our life, is also toxic ("oxygen paradox"). This is due to its ability to generate reactive intermediates (superoxide anion, hydroxyl radical, hydrogen peroxide, singlet oxygen, perferryl ion, nitrogen oxides) (see [1]).

In the 19th century, this "oxygen paradox" was described for the first time by Louis Pasteur, when he demonstrated that anaerobic organisms rapidly died after exposure to air containing the $20 \%$ oxygen required for the survival of aerobic organisms. In the middle of 1950s, Gerschman et al. [2] and Harman [3] resurrected this concept and respectively postulated the hypothesis that death of animals exposed to X-irradiation in presence of high oxygen tensions and the aging process were partially due to abnormal metabolism of oxygen, leading to toxic free-radical reactions. In France, Laborit et al. [4] attracted everyone's attention to the possible toxicity of high-pressure oxygen in divers through the production of free radicals, and suggested the use of certain antioxidants in biology. As discussed in detail in this book, a free radical (superoxide anion, hydroxyl radical) is defined as any species capable of independent existence that contains one or more unpaired electrons. This confers high reactivity to the molecule and, therefore, allows it to damage multiple 
biological substrates, including proteins, lipoproteins, deoxyribonucleic acid (DNA), carbohydrates, and polyunsaturated fatty acids. Moreover, they can also act as second messengers in the induction of molecular processes [5].

The "free radical story" in biology and medicine really started with the discovery by McCord, Keele and Fridovich in 1969 [6] of superoxide dismutase, an enzyme capable of destroying the superoxide anion radical resulting from the univalent reduction of oxygen. Since then, there has been an exponential increase in scientific articles indicating that excessive production of "reactive oxygen species" (ROS) or "free radical" is implicated in the pathogenesis of diseases in humans. Currently, Free Radicals in Biology and Medicine and Free Radicals Research Communications are the two specific journals encompassing medical approaches to oxygen free radical research.

\section{When does free radical production become dangerous?}

If reactive oxygen species are generally regarded as dangerous, it must be kept in mind that our metabolism produces free radicals under normal conditions. Thus, a small amount of oxygen (2\%) is continuously reduced to ROS in the mitochondrial electron transport chain. Moreover, free radical species also play a key role in many physiologic reactions. Typical examples are the killing of bacteria by granulocytes and macrophages [7], the oxidation of xenobiotics by cytochrome P-450 [8], the regulation of smooth muscle by "endothelium-derived relaxing factor" (EDRF), now recognised as the nitric oxide (NO') radical, and even fertilization [9]. To regulate these free radical reactions, our organism has developed antioxidant defenses including not only enzymes (superoxide dismutase, catalase, glutathione peroxidase) and small molecules (vitamins A, C, and E, uric acid, glutathione, albumine or bilirubin), but also repair systems which prevent the accumulation of oxidatively damaged molecules.

However, in human diseases, increased free radical activity can occur either as a primary (e.g., excess radiation exposure) or a secondary (e.g., tissue damage by trauma) event, mediated by several biochemical processes: extracellular release of ROS by granulocytes, xanthine oxidase activation, iron release from sequestered sites, phospholipase activation, alteration of electron transport in the mitochondrion, etc. Consequently, antioxidant defenses can be rapidly overwhelmed, leading to increased tissue injury. These situations can be considered as "oxidative stress" since, as defined in detail by Sies [10], there is a profound disturbance of the prooxidant-antioxidant balance in favour of the former, leading to lipid peroxidation, denaturation of proteins or enzymes or mutagenic damage to nucleic acids. The dual nature of free 
radicals in biological systems is perfectly illustrated by activated neutrophils, which can be involved in both physiologic (bacteria killing with controlled intracellular production of ROS) and pathophysiologic (inflammation with uncontrolled extracellular production of ROS) events. Similarly, excessive production of $\mathrm{NO}^{*}$, initiated by activation of the glutamate receptor after cerebral ischemia, is thought to participate in tissue injury in the brain (via the generation of oxidizing peroxynitrite anion from the reaction between the superoxide anion and nitric oxide).

\section{A critical point: Assays for measuring free radical formation in vivo}

Increased ROS formation has been implicated in over 100 pathophysiologic conditions [11]. The transient nature of free radicals makes in vivo assessment of their production a difficult challenge; the role of ROS in such a variety of processes may reflect this difficulty.

Most currently used techniques are called "fingerprint assays," because they examine the chemical changes that free radicals caused by interacting with targets such as lipids, proteins and DNA as measured by end-products of lipid peroxidation, protein carbonyls and 8-hydroxyguanine. Until recently, the most popular method involved the measurement of malondialdehyde (MDA) and thiobarbituric acid-reactivity as markers of lipid peroxidation [12], but this assay lacks specificity and accuracy. This has led to some controversy about the importance of free radicals in human diseases. Detection of other molecules, such as 4-hydroxynonenal or hydrocarbons (ethane, pentane), has also been proposed to assess lipid peroxidation, but these too require great care in data interpretation [13].

A more realistic strategy for monitoring free radical reactions in vivo is the measurement of antioxidant defences present in human plasma [14], red blood cells, and even tissue. As a typical example, vitamin E or $(\alpha$-tocopherol), acting as a chain-breaking antioxidant, can protect membrane lipids against oxidative damage by virtue of its potent scavenging. Its consumption can thus be considered to be a specific, although indirect, index of in vivo peroxidative processes [15]. Measuring the product of attack of ROS on uric acid has also been proposed as a potential marker of oxidative damage [16].

All of this evidence is, however, indirect and does not afford detailed information about the exact role played by free radicals in including in vivo tissue injury. Efforts have been made recently to directly demonstrate the formation of free radicals in biological samples as complex as blood or plasma, using the techniques of aromatic hydroxylation (e.g., salicylate, see [17]) and spin trapping associated with electron spin resonance (ESR) spectroscopy, as trapping assays. 
The ESR methodology is currently considered to be the technique of choice for detecting free radicals in vivo since it allows to detect the free radical by measuring the absorption of energy due to interaction of the unpaired electron present in the free radical with an applied external magnetic field produced by a magnet. Direct ESR can detect the ascorbyl radical in plasma at room temperature or the NO radical in frozen blood [18]. More often, however, spin trapping agents are required in ESR to increase the half life of free radicals generated in vivo. Such agents react with short-lived free radicals to form more stable species (spin adducts) that can be detected, identified and sometimes quantitated. Numerous spin trapping agents, such as 5,5-dimethyl-1pyrroline 1-oxide (DMPO) or alpha-phenyl-N-tert-butyl nitrone (PBN) are available. These agents cannot be administered safely to human patients, but this problem can be avoided by using a non-invasive spin-trapping technique involving drawing blood samples into syringes containing the spin-trap agent (ex-vivo reaction). (For a general review about all described methodologies, see [19].)

\section{Some examples of human diseases associated with free radicals}

Clinical conditions in which free radicals are though to be involved are numerous. For a complete listing, we suggest reviews by Halliwell [20] and Gutteridge [11]. Diseases may be classified into two groups depending on the target (Fig. 1). Inflammatory-immune injury [21], ischemiareflow states [22], drug toxicity [23], iron overload [24], nutritional deficiences [25], alcohol toxicity [26], radiation injury [27], aging [28], cancer [29] and amyloid diseases [30] belong to the first group. In the primary single organ group are found erythrocytes [31], blood vessels [32, 33], lung [34-36], the heart and cardiovascular system [37], kidney $[38,39]$, the gastrointestinal tract [40], joint abnormalities [41, 42], brain [43-45], eye [46] and skin [47].

In 1990, Sinclair et al. [48] classified diseases associated with increased free radical production as having an intracellular (hyperoxygenation, hypo-oxygenation, chemicals and drugs, alcoholic liver disease, haemolytic iron overload, Parkinson's disease, aging), an extracellular (inflammatory states, immunological and autoimmune diseases, diabetes mellitus, atherosclerosis, cataractogenesis), or both intra- and extracellular (radiation, chemical carcinogens, smoking, air polluants) origin.

More recently, Bulkley [49] classified the human diseases into groups based on pathophysiologic categories: chemical and xenobiotic toxicity, radiation injury, hyperoxygenation syndromes, inflammatory conditions, postischemic reperfusion injury and degenerative conditions.

Herein only a limited number of examples will be discussed: ischemiareperfusion states in cardiac surgery and organ transplantation, septic 


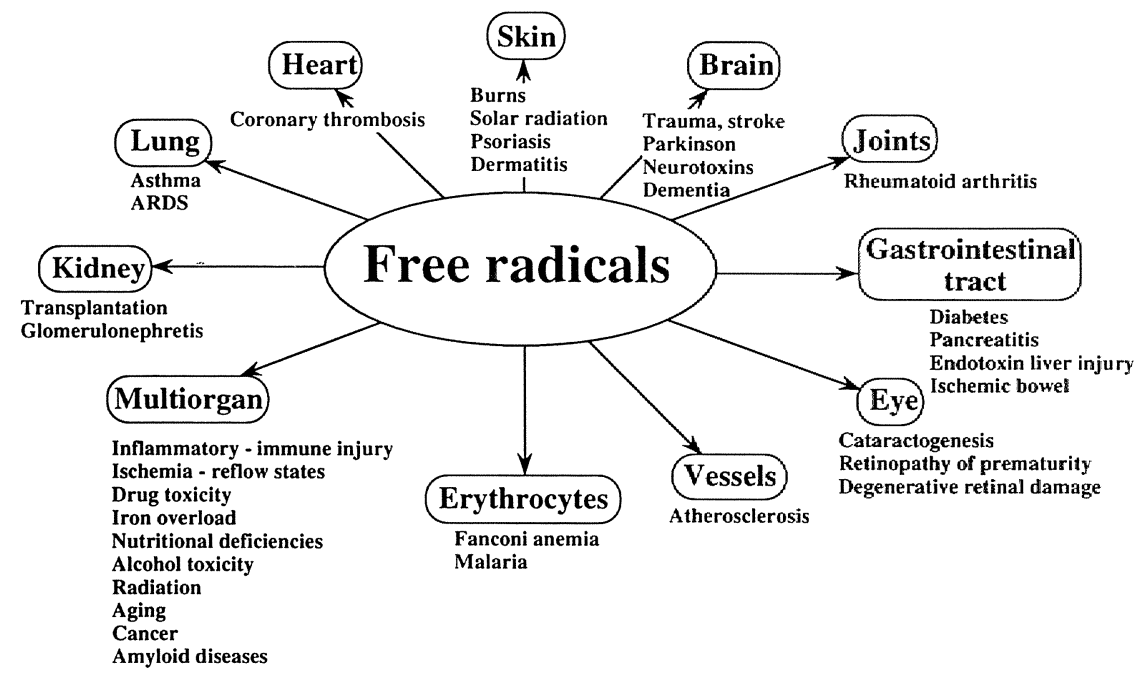

Fig. 1. Spectrum of human diseases where an excessive free radical production is thought to play a significant role in developing tissue injury. For each pathology, the reader will find references in text.

shock, rheumatoid arthritis and acquired immunodeficiency syndrome (AIDS).

\section{Ischemia-reperfusion}

Ischemia-reperfusion injury is a field that has been seized upon largely by clinical investigators. It is considered to play a major role in the organ dysfunction accompanying trauma, shock and sepsis, but also in cardiovascular diseases and organ transplantation.

Interruption of blood flow (ischemia) to an organ results in a cascade of biochemical events that predispose to production of increased reactive oxygen species on reperfusion. This has been unequivocally demonstrated by ESR spin trapping studies in both in vitro and in animal models [50-56a]. Sources of free radicals in the reperfused organ are: activation of xanthine oxidase and phospholipase, alteration in the electron transport chain, where superoxide anion is produced at two sites (ubiquinone and NADH dehydrogenase), increased metabolism of arachidonic acid by cyclooxygenase and lipooxygenase, accumulation and activation of granulocytes, hemoglobin oxidation and iron release from ferritin mediated by superoxide anion [56b].

\section{Myocardial ischemia}

Clinically, reperfusion of ischemic myocardium is recognized as beneficial because mortality is directly related to infarct size, which in turn is 
related to the severity and duration of ischemia. However, restoration of normal blood flow to the heart using methods such as angioplasty, thrombolytic agents or aorta-coronary bypass grafting, can lead to specific lesions (arrhythmias, decreased in contractility, necrosis), the importance of which is dependent on the time of ischemia. Using ESR methodology with blood drawn into PBN, Coghlan et al. [57] showed an increased free radical production after reperfusion of infracting tissue in a patient undergoing delayed repair of a transected aorta. The same authors also demonstrated ESR signals in blood taken from the coronary sinus of patients undergoing percutaneous transluminal coronary angioplasty, as ideal model of myocardial ischemia-reperfusion [37]. Because only small ESR signals could be detected during ischemia, the authors concluded that reperfusion was a necessary condition for significant detection of radicals. In patients undergoing cardiopulmonary bypass (CPB) for cardiac surgery (repair of aortic aneurysms, coronary bypass grafting), an increased free radical activity in plasma has been shown to occur following aortic unclamping as shown by increased granulocyte activation [58], loss of antioxidant [59-61], iron overload [62], protein oxidation [63] and the appearance of ESR signals in blood drawn into spin-trapping agents $[64,65]$.

\section{Organ transplantation}

Organ transplantation is a typical example of ischemia-reperfusion, since between harvesting and reperfusion in the recipient, the procedure includes several steps during which severe damage to the organ can occur: cardioplegic arrest (only for heart transplantation) and cooling, storage for varying periods (cold ischemia), warm ischemia during the surgical procedure, and reperfusion. In humans, few studies have been conducted to investigate the generation of free radical under such condition [66-68]. During human kidney transplantation, we observed a decrease of antioxidant vitamin $\mathrm{E}$ early after the onset of reperfusion in blood samples specifically from the renal vein, when compared to the value observed in the renal artery just before reperfusion (Fig. 2). A similar decrease was shown in the systemic blood, indicating the occurrence of lipoperoxidation processes [39]. Using ESR methodology, we also directly demonstrated that a burst of free radical production occurred within the first minutes of reperfusion; this was related to increased granulocyte activation. Oxidative damage has also been shown to occur in human liver transplantation.

\section{Septic shock}

Severe shock or trauma are often associated with organ dysfunction occurring days after the initiating event. This is also seen after septic 


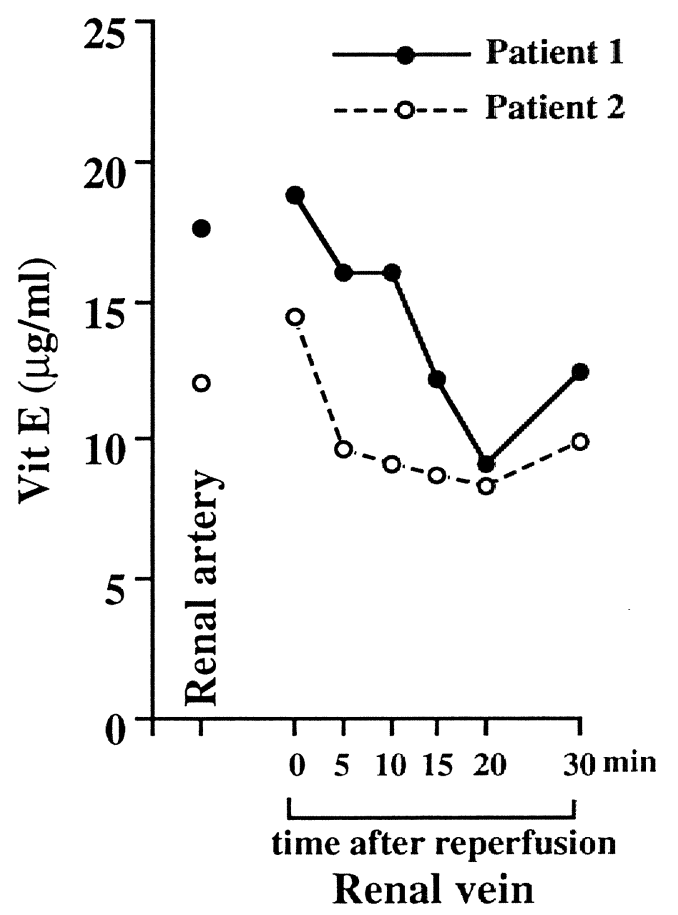

Fig. 2. Evidence of lipid peroxidation processes during human kidney transplantation (two patients) as assessed by the decrease of vitamin $\mathrm{E}$ in blood specifically taken from the renal vein since the beginning of graft reperfusion. Reference value was that found in the blood sample drawn from the renal artery just prior to inducing reperfusion.

shock, defined as sepsis with hypotension despite adequate fluid resuscitation, in the presence of perfusion abnormalities. Among the several syndromes which are related to septic shock in man are the adult respiratory distress syndrome (ARDS) or "shock lung syndrome" and multiple systems organ failure (MSOF).

Many papers provide evidence for increased free radical activity in such diseases, which often have a fatal outcome. Because of changes in microcirculatory perfusion, ischemia-reperfusion phenomena are present in sepsis and are considered to be the main source of radical production [69]. In ARDS and septic patients, neutrophils are also another important source; they have been shown to be in an activated state, as demonstrated by high levels of neutrophil proteins (myeloperoxidase, elastase) found in plasma [70] and in bronchoalveolar lavage (BAL) fluids [71] of such patients. $\alpha 1$-proteinase oxidized by excess production of hypochlorous acid (mediated by MPO activity) can be detected in BAL fluid of ARDS patients [71]. Other evidence for increased rates of lipid peroxidation and oxidative damage to proteins as well as depletion of plasma antioxidants has been described in 
critically ill patients, in ARDS patients, and during human septic shock [72-79]. Serum catalase was found to be increased in ARDS patients with sepsis [80]. Both hydrogen peroxide and pentane were found in the expired air of ARDS patients [81, 82]. Despite all this evidence, it is, however, not clear if oxidative stress is a significant mediator of organ injury in ARDS and/or MSOF. The clinical trials with antioxidant therapies are crucial to clarify this question.

\section{Rheumatoid arthritis}

The glycoaminoglycan hyaluronate rapidly loses its viscosity in the presence of free radical generating systems; this can be correlated with the decreased viscosity of synovial fluid from the joints of patients with rheumatoid arthritis. The presence of activated neutrophils [83] as well as the release of iron from lysed cells contribute to free radical activity [84]. Evidence consistent with oxidative stress in rheumatoid disease is abundant although indirect: increased exhalation of pentane [41], increased products of lipid peroxidation [85], loss of antioxidant in both serum and synovial fluid [85], the presence of oxidation products of uric acid [16], and evidence of aromatic hydroxylation [17].

\section{Acquired immunodeficiency syndrome (AIDS)}

Recently, a considerable number of papers has been devoted to oxygen free radicals in AIDS (see [86]). Caused by the human immunodeficiency virus (HIV), this disease is characterized by depletion of the T4+ T-cell population and cellular dysfunction that affects several cell types such as the T8 + T-cell subset.

Numerous studies have shown that the generation of activated oxygen species is impaired in mononuclear phagocytes from HIV-infected patients. In a very elegant study, Postaire et al. [87] have described increased release of pentane (a marker of lipid peroxidation) in the alveolar air of HIV patients. An increasing number of investigations has shown that HIV patients were severely depleted of antioxidants (for review, see [88]). GSH levels were profoundly depressed both in plasma and in peripheral blood mononuclear cells and lymphocytes $[89,90]$. In comparison to healthy subjects, Favier et al. [91] reported, in stages II and IV of the disease, very low levels of all antioxidant micronutrients, particularly carotene. Retinol deficiency is also observed [92]. Moreover, several workers have clearly established a significant deficiency in trace element factors, especially of selenium [92]. This element is related to antioxidant activity via the enzyme glutathione peroxidase which is decreased significantly in plasma of patients in stages II and IV [91]. 
These data indicate the presence of an oxidative stress (a profound imbalance between prooxidant and antioxidant activities) during HIV infection. This is of primordial importance, since in vitro studies have revealed that oxidative stress can activate the HIV transactivation [93] by stimulating transcription of the nuclear factor $\kappa-\mathrm{B}(\mathrm{NF}-\kappa \mathrm{B})$ [5]. On the basis of all these observations, a place for an antioxidant therapy in HIV infection has been suggested.

\section{Antioxidant therapy}

The studies described above suggest that excessive free radical production occurs in many human diseases. Currently, the prevalent idea is that an initial insult induces a secondary increase in the rate of free radical production, and that oxidative damage exacerbates the primary tissue injury. Whatever the precise mechanism, preventing free radical generation should provide beneficial clinical consequences, and development of appropriate antioxidant therapy represents an important challenge for the future.

As previously reported, an antioxidant can be defined as "any substance that, when present at low concentrations compared to those of the oxidizable substrate, significantly delays, or inhibits, oxidation of that substrate" [1]. However, an antioxidant may act at a different stage of the production of free radicals, therefore making the design of appropriate antioxidant drugs for clinical studies difficult. Antioxidant substances can be divided into two large classes - those with enzymatic and those with non-enzymatic activities. In the first group are enzymes that remove ROS (superoxide dismutase, catalase, glutathione peroxidase), molecules blocking enzymatic activity (e.g., allopurinol, xanthine oxidase inhibitor) and molecules capable of trapping metal ions, which are potent catalysts of free radical reactions (desferrioxamine or lazaroid compounds). In the second group are molecules which interact mole by mole with the free radical and are, therefore, consumed during the reaction. Vitamin A (a quencher of singlet oxygen), vitamin C, glutathione, mannitol, albumin, probucol, N-Acetylcysteine are such free radical scavengers. Also in this group, vitamin E has a special status since, as a lipid soluble chain-breaking antioxidant, it is also consumed; it can, however, be regenerated via a catalytic cycle involving glutathione or ascorbic acid.

Meetings are increasingly organized throughout the world to critically consider the role of antioxidants in therapy. Several papers have recently reviewed in detail current studies using antioxidants in several human diseases [27, 33, 36, 49, 94-110].

Despite encouraging results [106, 109-113], most studies on the role of antioxidants in humans have been rather disappointing $[114,115]$. 
In the concluding remarks of his talk at the meeting "Antioxidant Therapy - The Way Forward", which was held in Liverpool in 1993, Professor Gutteridge recognized "that, so far, antioxidants have made little or no impact on the treatment of serious diseases" (SFFR Newsletter nr. 14, 1994). The lack of efficacy could be attributed to difficulties in site-delivery of the drug (see [116] and [117] for SOD) at appropriate concentrations [56]. During ischemia-reperfusion studies on animals, the timing of antioxidant administration (before, during of after reperfusion, following short or long ischemia times) appears to be crucial to the outcome of the study. It is therefore crucial to define a therapeutic window for antioxidants during ischemia-reperfusion [107]. At least it should also be kept in mind that any antioxidant agent can be associated with a pro-oxidant action. An example is seen with ascorbic acid in the presence of iron [118], but also with N-acetylcysteine, which may generate thiol-derived free radical species [119]. This could therefore limit the beneficial effect of administration of thiol antioxidants. A pro-oxidant activity for desferrioxamine has also recently been described [120].

\section{Conclusions}

There is increasing evidence implicating free radical generation in clinical situations. However, there is also a great deal of confusion about the precise role of these species in the development of human diseases. Because of this, the use of reliable markers for detecting reactive oxygen species in clinical situations is absolutely necessary. Due to its direct nature, we feel that the use of electron spin resonance spectroscopy, especially the actual development of a new generation of devices, for in vivo studies, may become feasible in the near future. Indeed, because of its ability to provide an integrated measure of free radical production over a given interval of time (e.g., in ischemia-reperfusion states), this methodology can delineate the time-course of production of free radicals. Direct correlation between free radical production and clinical parameters should become possible; this would be helpful to clarify our knowledge about antioxidant therapy, which is now considered as controversial [121] or even a myth [122].

\section{References}

1. Gutteridge, J.M.C. (1994a) Biological origin of free radicals, and mechanisms of antioxidant protection. Chemico-Biological Interactions 91: 113-140.

2. Gerschman, R., Gilbert, D.L., Nye, S.W., Dwyer, P. and Fenn, W.O. (1954) Oxygen poisoning and x-irradiation: a mechanism in common. Science 119: 623-626.

3. Harman, D. (1956) Aging: a theory based on free radical and radiation chemistry. $J$. Geront 11: 298-300. 
4. Laborit, H., Baron, C., Berthou, J., Drouet, J., Gerard, J., Jouany, J.M., Narvaes, C., Niaussat, P and Weber, B. (1960) Introduction à l'étude des antioxydants et des structures à électrons célibataires en biologie. 2ème partie: étude expérimentale et réanimation métabolique. Agressologie 1: 133-155.

5. Paeck, R., Rubin, P. and Bauerle, P.A. (1991) Reactive oxygen intermediates as apparently widely used messengers in the activation of the NF- $\kappa \mathrm{B}$ transcription factor and HIV. EMBO J. 10: 2247-2258.

6. McCord, J.M., Keele, B.B., Jr. and Fridovich, J.J. (1969) Superoxide dismutase, an enzyme function for erythrocuprein. J. Biol. Chem. 244: 6049-6055.

7. Klebanoff, S.J. (1982) The iron-H202-iodide cytotoxic system. J. Exp. Med. 156: $1262-1267$.

8. Bast, A. (1986) Is formation of reactive oxygen species by cytochrome P-450 perilous and predictable? Biochem. Pharmacol. 37: 569-571.

9. Shapiro, B.M. (1991) The control of oxidant stress at fertilization. Science 252: 533-536.

10. Sies, H. (1991) In: H. Sies (ed.): Oxidative Stress. Oxidants and Antioxidants. Academic Press, London, pp 15-22.

11. Gutteridge, J.M.C. (1993) Invited review free radicals in disease processes: a complication of cause and consequence. Free Rad. Res. Comm. 19: 141-158.

12. Janero, D.R. (1990) Malondialdehyde and thiobarbituric acid reactivity as diagnostic indices of lipid peroxidation and peroxidative tissue injury. Free Rad. Biol. Med. 9: $515-540$.

13. Springfield, J.R. and Levitt, M.D. (1994) Pitfalls in the use of breath pentane measurements to assess lipid peroxidation. J. Lip. Res. 35: 1497-1504.

14. Stocker, R. and Frei, B. (1991) Endogenous antioxidant defences in human blood plasma. In: H. Sies (ed.): Oxidative Stress. Oxidants and Antioxidants. Academic Press, London, pp 213-243.

15. Burton, G.W. and Ingold, K.U. (1989) Vitamin E as an in vitro and in vivo antioxidant. In: A.T. Diplock, L.J. Machlin, L. Packer and W.A. Pryor (eds): Vitamin E Biochemistry and Health Implications. Vol. 570, Ann. New York Acad. Sci., pp 7-22.

16. Grootveld, M. and Halliwell, B. (1987) Measurement of allantoin and uric acid in human body fluids. A potential index of free radical reactions in vivo? Biochem. J. 243 : 803-808.

17. Grootveld, M. and Halliwell, B. (1986) Aromatic hydroxylation as potential measure of hydroxyl radical formation in vivo. Identification of hydroxylated derivatives of salicylate in human body fluids. Biochem. J. 237: 499-504.

18. Cantilena, L.R., Smith, R.P., Frasur, S., Kruszyna, H., Kruszyna, R. and Wilcox, D.E. (1992) Nitric oxide hemoglobin in patients receiving nitroglycerin as detected by electron paramagnetic resonance spectroscopy. J. Lab. Clin. Med. 120: 902-907.

19. Pryor, W.A. and Godber, S.S. (1991) Noninvasive measures of oxidative stress status in humans. Free Rad. Biol. Med. 10: 177-184.

20. Halliwell, B. (1987) Oxygen radicals and metals ions: potential antioxidant intervention strategies In: C.E. Cross (ed.): Oxygen Radicals and Human Disease. Ann. Intern. Med. 107: $526-545$

21. Lunec, J. (1991) Free radicals and the immune response. Molec. Aspects Med. 12: $85-174$.

22. Powell, S.R. and Tortolani, A.J. (1992) Recent advances in the role of reactive oxygen intermediates in ischemic injury. J. Surg. Res. 53: 417-429.

23. Hecht, S.M. (1986) DNA strand scission by activated bleomycin group antibiotics. Fed. Proc. 45: 2784-2791.

24. Young, I.S., Trouton, T.G., Torney, J.J., McMaster, D., Callender, M.E. and Trimble, E.R. (1994) Antioxidant status and lipid peroxidation in hereditary haemochromatosis. Free Rad. Biol. Med. 16: 393-397.

25. Chiu, D. and Lubin, B. (1980) Abnormal vitamin E and glutathione peroxidase levels in sickle cell anemia: evidence for increased susceptibility to lipid peroxidation in vivo. $J$. Lab. Clin. Med. 94: 542-548.

26. Peters, T.J., O'Connell, M.J., Venkatesan, S. and Ward, R.J. (1986) Evidence for free radical-mediated damage in experimental and human alcoholic disease. In: C. RiceEvans (ed.): Free Radicals, Cell Damage and Disease. Richelieu Press, London, pp $99-110$. 
27. Korkina, L.G., Afanas'ef, I.B. and Diplock, A.T. (1993) Antioxidant therapy in children affected by irradiation from the Chernobyl nuclear accident. Biochem. Soc. Trans. 2l(3): $314 \mathrm{~S}$.

28. Mecocci, P., MacGarvey, U., Kaufman, A. Koontz, D., Shoffner, J.M., Wallace, D.C. and Beal, M.F. (1993) Oxidative damage to mitochondrial DNA shows marked age-dependent increases in human brain. Ann. Neurol. 34: 609-616.

29. Frey, K.F., Brubacher, G.B. and Stähelin, H.B. (1987) Plasma levels of antioxidant vitamins in relation to ischemic heart disease and cancer. Am. J. Clin. Nutr. 45: $1368-1377$

30. Harman, D. (1984) Free radical theory of aging: the "free-radical diseases". Age 7: $111-131$.

31. Clark, I.A. and Hunt, N.H. (1983) Evidence for reactive oxygen intermediates causing hemolysis and parasite death in malaria. Infect. Immun. 39: 1-6.

32. Janero, D.R. (1991) Therapeutic potential of vitamin $E$ in the pathogensis of spontaneous atherosclerosis. Free Rad. Biol. Med. 11: 129-144.

33. Illingworth, D.R. (1993) The potential role of antioxidants in the prevention of atherosclerosis. J. Nut. Sc. Vitam. 39: S43-S47.

34. Pincemail, J., Bertrand, Y., Hanique, G., Denis, B., Leenaerts, L., Vankeerberghen, L. and Deby, C. (1989a) Evolution of vitamin E deficiency in patients with adult respiratory distress syndrome. Ann. NY Acad. Sci. 570: 498-499.

35. Malvy, J.-M., D., Lebranchu, Y., Richard, M.-J., Arnaud, J. and Favier, A. (1993) Oxidative metabolism and severe asthma in children. Clin. Chim. Acta. 218: 117-120.

36. Leuenberger, P. (1994) Respiratory diseases and oxidants. Schweiz. Medizin. Wochenschrift. 124: 129-135.

37. Coghlan, J.G., Flitter, W.D., Holle, A.E., Norell, M., Mitchell, A.G., Ilsley, C.D. and Slater, T.F. (1991a) Detection of free radicals and cholesterol hydroperoxides in blood taken from the coronary sinus of man during percutaneous transluminal coronary angioplasty. Free Rad. Res. Comm. 14: 409-417.

38. Johnson, K.J., Rehan, A. and Ward, P.A. (1987) Upjohn Symposium. The role of oxygen radicals in kidney disease. Kidney Disease, pp 115-121.

39. Pincemail, J., Defraigne, J.O., Franssen, C., Bonnet, P., Deby-Dupont, G., Pirenne, J., Deby, C., Lamy, M., Limet, M. and Meurise, M. (1993) Evidence for free radical formation during human kidney transplantation. Free Rad. Biol. Med. 15: 343-348.

40. Scott, P., Bruce, C., Schofield, D., Shiel, N., Braganza, J.M. and McCloy, R.F. (1993) Vitamin C status in patients with acute pancreatitis. Br. J. Surg. 80: 750-754.

41. Humad, S., Zarling, E., Clapper, M. and Skosey, J.L. (1988) Breath pentane excretion as a marker of disease activity in rheumatoid arthritis. Free Rad. Res. Comm. 5: $101-106$.

42. Meier, B., Radeke, H.H., Selle, S., Raspe, H.H., Sies, H., Resch, K. and Habermehl, G. (1990) Human fibroblasts release reactive oxygen species in response to treatment with synovial fluids from patients suffering from arthritis. Free Rad. Res. Comm. 8: 149-160.

43. Hall, E.D. and Braughler, J.M. (1989) Central nervous system trauma and stroke. II. Physiological and pharmacological evidence for involvement of oxygen radicals and lipid peroxidation. Free Rad. Biol. Med. 6: 303-313.

44. Adams, J.D. and Odunze, I.N. (1991) Oxygen free radicals and Parkinson's disease. Free Rad. Biol. Med. 10: 161-169.

45. Girotti, M.J., Khan, N. and McLellan, B.A. (1991) Early measurement of systemic lipid peroxidation products in the plasma of major blunt trauma patients. J. of Trauma 31: $32-35$.

46. Spector, A. (1991) The lens and oxidative stress. In: H. Sies (ed.): Oxidative Stress. Oxidants and Antioxidants. Academic Press, London, pp 529-558.

47. Fuchs, J. and Packer, L. (1991) Photooxidative stress in the skin. In: H. Sies (ed): Oxidative Stress, Oxidants and Antioxidants. Academic Press, London, pp 559-583.

48. Sinclair, A.J., Barnett, A.H. and Lunec, J. (1990) Free radicals and antioxidant systems in health and disease. Brit. J. Hosp. Med. 43: 334-344.

49. Bulkley, G.B. (1993) Free radicals and other reactive oxygen metabolites: clinical relevance and the therapeutic efficacy of antioxidant therapy. Surgery 113: 479-483.

50. Garlick, P.B., Davies, M.J., Hearse, D.J. and Slater, T.F. (1987) Direct detection of free radicals in the reperfused rat heart using electron spin resonance spectroscopy. Cir. Res. 61: 757-760. 
51. Pietri, S., Culcasi, M. and Cozzone, P.J. (1989) Real-time continuous-flow spin trapping of hydroxyl radical in the ischemic and post-ischemic myocardium. Eur. J. Biochem. 186: 163-173.

52. Nilsson, U.A., Lundgren, O., Haglind, E. and Bylund-Fellenius, A.C. (1989) Radical production during in vivo intestinal reperfusion in the cat. Am. J. Physiol. 257: G409G414.

53. Pincemail, J., Defraigne, J.O., Franssen, C., Defechereux, T., Canivet, J.-J., Philippart, C. and Meurisse, M. (1990) Evidence of in vivo free radical generation by spin trapping with alpha-phenyl N-tert-butyl nitrone during ischemia-reperfusion in rabbit kidneys. Free Rad. Res. Comm. 9: 3-6.

54. Tosaki, A., Bagchi, D., Pali, T., Cordis, G.A. and Das, D.P. (1993) Comparisons of esr and HPLC methods for the detection of $\mathrm{OH}^{\cdot}$ radicals in ischemic-reperfused hearts. Biochem. Pharmacol. 45: $961-969$.

55. Li, X.Y., McCay, P.B., Zughaib, M., Jeroudi, M.O., Triana, J.F. and Bolli, R. (1993) Demonstration of free radical generation in the "stunned" myocardium in the conscious dog and identification of major differences between conscious and open-chest dogs. $J$. Clin. Invest. 92: 1025-1041.

56a Connor, H.D., Gao, W., Mason, R.P. and Thurman, R.G. (1993) New reactive oxidizing species causes formation of carbon-centered radical adducts in organic extracts of blood following liver transplantation. Free Rad. Biol. Med. 16: 871-875.

56b Omar, B., McCord, J. and Downey, J. (1991) Ischemia-reperfusion. In: H. Sies (ed.): Oxidative Stress. Oxidants and Antioxidants. Academic Press, London, pp 494-527.

57. Coghlan, J.G., Flitter, W.D., Isley, C.D., Rees, A. and Slater, T.F. (1991b) Reperfusion of infarcted tissue and free radicals. Lancet 338: 1145.

58. Faymonville, M.E., Pincemail, J., Duchateau, M.D., Paulus, J.M., Adam, A., Deby-Dupont, G., Deby, C., Albert, A., Larbuisson, R., Limet, R. and Lamy, M. (1991) Myeloperoxidase and elastase as markers of leukocyte activation during cardiopulmonary bypass in humans. J. Thorac. Cardiovasc. Surg. 102: 309-317.

59. Cavarocchi, N.C., England, M.D., O'Brien, J.F., Solis, E., Russo, P., Schaff, H.V., Orszulak, T.A., Pluth, J.R. and Kaye, M.P. (1986) Superoxide generation during cardiopulmonary bypass: is there a role for vitamin E. J. Surg. Res. 40: 519-527.

60. Pincemail, J., Faymonville, M., Deby-Dupont, G., Thirion, A., Deby, C. and Lamy, M. (1989b) Neutrophils activation evidenced by plasmatic myeloperoxidase release during cardiopulmonary bypass. Consequence on vitamin E status. Ann. NY Acad. Sci. 570: $501-502$.

61. Murphy, M.E., Kolvenback, R., Aleksis, M., Hansen, R. and Sies, H. (1992) Antioxidant depletion in aortic crossclamping ischemia: increase of the plasma alpha tocopheryl quinone/alpha-tocopherol ratio. Free Rad. Biol. Med. 13: 95-100.

62. Pepper, J.R., Mumby, S. and Gutteridge, J.M.C. (1994) Transient iron-overload with bleomycin-detectable iron present during cardiopulmonary bypass surgery. Free Rad. Res. Comm. 21: 53-58.

63. Ward, A., McBurney, A. and Lunec, J. (1994) Evidence for the involvement of oxygenderived free radicals in ischemia-reperfusion injury. Free Rad. Res. Comm. 20: 21-28.

64. Culcasi, M., Pietri, S., Carrière, I., d'Arbigny, P. and Drieu, K. (1993) Electron-spin-resonance study of the protective effects of Ginkgo biloba (EGb 761) on reperfusion-induced free-radical generation associated with plasma ascorbate consumption during open-heart surgery in man. In: C. Ferradini, M.T. Droy-Lefaix and Y. Christen (eds): Advances in Gingko biloba Extract Research, Vol 2. Ginkgo Biloba (EGb 761) as Free Radical Scavenger pp 153-162.

65. Hartstein, G., Pincemail, J., Deby-Dupont, G., Deby, C., Larbuisson, R. and Lamy, M. (1993) Evidence for free radical formation during cardiopulmonary bypass in man. Anesthesio. 79: no. 3A A140.

66. Heim, K.F., Makila, U.-M., Leveson, R., Ledley, G.S., Thomas, G., Rackley, C. and Ramwell, P.W. (1987) Detection of pentane as a measurement of lipid peroxidation in humans using gas chromatography with a photoionization detector. In: M. PaubertBraqut (ed.): Lipid Mediators in the Immunology of Shock. Nato ASI Series vol., 139. Plenum Press, New York, pp 103-108.

67. Serino, F., Citterio, F., Lippa, S., Oradei, A., Agnes, S., Nanni, A., Pozzetto, A., Littaru, G. and Castagneto, M. (1990) Coenzyme Q, alpha tocopherol and delayed function in human kidney transplantation. Transpl. Proc. 22: 2224-2225. 
68. Rabl, H., Khoschorur, G., Colombo, T., Tatzber, F. and Esterbauer, H. (1992) Human plasma lipid peroxide levels show a strong transient increase after successful revascularization operations. Free Rad. Biol. Med. 13: 281-288.

69. Zimmerman, J.J. (1992) Oxyradical pathogenesis in sepsis. In: M. Lamy and L.G. Thijs (eds): Update in Intensive Care and Emergency Medicine. Mediators of Sepsis. Vol. 16, pp $136-151$.

70. Pincemail, J., Deby-Dupont, G., Deby, C., Thirion, A., Torpier, G., Faymonville, M., Damas, P., Tomassini, M., Lamy, M. and Franchimont, P. (1991) Fast double antibody radioimmunoassay of human granulocytes myeloperoxidase and its application to plasma. J. Immunol. Meth. 137: 181-191.

71. Cochrane, C.G., Spragg, R., Revak, S.D., Cohen, A.B. and McGuire, W.W. (1983) The presence of neutrophil elastase and evidence of oxidant activity in bronchoalveolar lavage fluid. Am. Rev. Resp. Dis. 127: S25-S27.

72. Takeda, K., Shimada, Y., Amano, M., Sakai, T., Okada, T. and Yoshiya, I. (1984) Plasma lipid peroxides and alpha-tocopherol in critically ill patients. Crit. Car. Med. 12: 957-959.

73. Bertrand, Y., Pincemail, J., Hannique, G., Denis, B., Leenaerts, L., Vankeerberghen, L. and Deby, C. (1986) Differences in tocopherol-lipid ratio in ARDS and no ARDS patients. Int. Car. Med. 15: 557-559.

74. Keen, R.R., Stella, L., Flanigan, P. and Lands, W.E.M. (1991) Differential detection of plasma hydroperoxides in sepsis. Crit. Care Med. 19: 1114-1119.

75. Ogilvie, A.C., Groeneveld, A.B.J., Straub, J.P. and Thijs, L.G. (1991) Plasma lipid peroxides and antioxidants in human septic shock. Int. Care Med. 17: 40-44.

76. Toonen, T.R., Lewandoski, J.R. and Zimmerman, J.J. (1991) Longitudinal analysis of plasma tocopherol levels in patients with septic shock. Clin. Res. 39: 688.

77. Krsek-Staples, J.A., Kew, R.R. and Wester, R.O. (1992) Ceruloplasmin and transferrin levels are altered in serum and bronchoalveolar lavage fluid of patients with the adult respiratory distress syndrome. Am. Rev. Respir. Dis. 145: 1009-1015.

78. Quinlain, G.J., Evans, T.W. and Gutteridge, J.M.C. (1994a) Oxidative damage to plasma proteins in adult respiratory distress syndrome. Free Rad. Res. Comm. 20: 289-298.

79. Quinlain, J.G., Evans, T.W. and Gutteridge, J.M.C. (1994b) Linoleic acid and protein thiol changes suggestive of oxidative damage in the plasma of patients with adult respiratory distress syndrome. Free Rad. Res. Comm. 20: 299-306.

80. Leff, J.A., Parsons, P.F., Day, C.E., Taniguchi, N., Jochum, M., Fritz, H., Moore, F.A., Moore, E., McCord, J.M. and Repine, J.E. (1993) Serum antioxidants as predictors of adult respiratory distress syndrome in patients with sepsis. Lancet 341 : 777-780.

81. Baldwin, S.R., Simon, R.H., Grum, C.M., Ketai, L.H., Boder, L.A. and Devall, L.J. (1986) Oxidant activity in expired breath of patients with adult respiratory distress syndrome. Lancet 1: 11-14.

82. Pincemail, J., Deby, C., Dethier, A., Bertrand, Y., Lismonde, M. and Lamy, M. (1986) Pentane measurement in man as an index of lipid peroxidation. Bioelectro. and Bioenerg. 18: $117-126$.

83. Nurcombe, H.L., Bucknall, R.C. and Edwards, S.W. (1991) Neutrophils isolated from the synovial fluid of patients with rheumatoid arthritis: priming and activation in vivo. Ann. Rheum. Dis. 50: 196-200.

84. Gutteridge, J.M.C. (1987) Bleomycin-detectable iron in the knee-joint synovial fluid from arthritic patients and its relationship to the extracellular antioxidant activities of caeruloplasmin, transferrin and lactoferrin. Lancet 2: 415-421.

85. Merry, P., Grootveld, M., Lunec, J. and Blake, D.R. (1991) Oxidative damage to lipids within inflamed human joints provides evidence of radical-mediated hypoxic-reperfusion injury. Am. J. Clin. Nutr. 56: 362S-369S.

86. The place of oxygen free radicals in HIV infections (1994), presented at a meeting organized in France by A.E. Favier, published in Chemico-Biological Interactions (Guest Editor A.E. Favier), Vol. 91, pp 77-232.

87. Postaire, E., Massias, L., Lopez, O., Mollerau, M. and Hazebroucq, G. (1994) Alcanes measurements in human immunodeficiency virus infection. In: C. Pasquier, R.Y. Olivier, C. Auclair and L. Packer (eds): Oxidative Stress, Cell Activation and Viral Infection. Birkhäuser Verlag, Basel, pp 333-340. 
88. Müller, F. (1992) Reactive oxygen intermediates and human immunodeficiency virus (HIV) infection. Free Rad. Biol. Med. 13: 651-657.

89. Staal, F.J.T., Roederer, M., Israelski, D.M., Buop, J., Mole, L.A., McShane, D., Deresinski, S.C., Ross, W., Sussman, H., Rago, P.A., Anderson, M.T., Moore, W., Elsa, W. and Hersenberg, L.A. (1992) Intracellular glutathione levels in T cells subset decrease in HIV infected patients. AIDS Res. Human Retroviruses 2: 311.

90. Dröge, W., Eck, H.-P., Mihm, S. and Galter, D. (1994) Abnormal redox regulation in HIV infection and other immunodeficiency diseases. In: C. Pasquier, R.Y. Olivier, C. Auclair and L. Packer (eds): Oxidative Stress, Cell Activation and Viral Infection. Birkhäuser Verlag, Basel, pp 285-299.

91. Favier, A., Sappey, C., Leclerc, P., Faure, P. and Micoud, M. (1994) Antioxidant status and lipid peroxidation in patients infected with HIV. Chemico-Biological Interactions 91: $165-180$.

92. Sergeant, C., Simonoff, M., Hamon, C., Peuchant, E., Dumon, M.F., Clerc, M., Thomas, M.J., Constans, J., Conri, C., Pelligrin, J.L. and Leng, B. (1994) Plasma antioxidant status (selenium, retinol and $\alpha$-tocopherol) in HIV infection. In: C. Pasquier, R.Y. Olivier, C. Auclair and L. Packer (eds): Oxidative Stress, Cell Activation and Viral Infection, Birkhäuser Verlag, Basel, pp 341-351.

93. Legrand-Poels, S., Vaira, D., Pincemail, J., Van de Vorst, A. and Piette, J. (1990) Activation of human immunodeficiency virus type 1 by oxidative stress. AIDS Res. 6 : $1389-1397$.

94. Uden, S., Bilton, D., Nathan, L., Hunt, L.P., Main, C., Braganza, J.M. (1990) Antioxidant therapy for reccurent pancreatitis: placebo-controlled trial. Alim. Pharmacol. Therapeu. 4: 357-371.

95. Clemens, M.R. (1990) Antioxidant therapy in hematological disorders. Ad. Exp. Med. Biol. 264: 423-433.

96. Anonymous (1990) Antioxidants in therapy and preventive medicine. Ad. Exp. Med. Biol. 264: 1-576.

97. Müller, D.P. (1990) Antioxidant therapy in neurological disorders. Adv. Exp. Med. Biol. 264: $475-484$.

98. Hearse, D.J. (1991) Prospects for antioxidant therapy in cardiovascular medicine. Am. $J$. Med. 91: 118S-121S.

99. Youn, Y.-K., LaLonde, C. and Demling, R. (1991) Use of antioxidant therapy in shock and trauma. Circ. Shock 35: 245-249.

100. Chow, C.K. (1991) Vitamin E and oxidative stress. Free Rad. Biol. Med. 11: 215-232.

101. Deucher, G.P. (1992) Antioxidant therapy in the aging process. In: I. Emerit and B. Chance (eds): Free Radicals and Aging, Birkhäuser Verlag, Basel, pp 428-437.

102. Manson, J.E., Gaziono, J.M., Jonas, M.A. and Hennkens, C.H. (1993) Antioxidants and cardiovascular disease. J. Am. Coll. Nut. 12: 426-432.

103. Goode, H.F. and Webster, N.R. (1993) Free radicals and antioxidants in sepsis. Crit. Care Med. 21: 1770-1776.

104. Packer, L. (1993) The role of anti-oxidative treatment in diabetes mellitus. Diabetol. 36 : $1212-1213$.

105. Levander, O.A. and Ager, A.L. (1993) Malarial parasites and antioxidant nutrients. Parasitology 107: S95-S106.

106. Sies, H. (1993) Efficacy of vitamin $E$ in the Human. Veris, Lagrange, Illinois, USA.

107. Schiller, H.J., Reilly, P.M. and Bulkley, G.B. (1993) Antioxidant therapy. Crit. Care. Med. 21: S92-S102.

108. Yoshikawa, T., Naito, Y. and Kondon, M. (1993) Antioxidant therapy in digestive diseases. J. Nutr. Sc. Vitam. 39: S35-S41.

109. Rice-Evans, C.A. and Diplock, A.T. (1993) Current status of antioxidant therapy. Free Rad. Biol. Med. 15: 77-96.

110. Baruchel, S., Bounous, G. and Gold, P. (1994) Place for an antioxidant therapy in human immunodeficiency virus (HIV) infection. In: C. Pasquier, R.Y. Olivier, C. Auclair and L. Packer (eds): Oxidative Stress, Cell Activation and Viral Infection. Birkhäuser Verlag, Basel, pp 311-321.

111. Parthasarathy, S. and Rankin, S.M. (1992) Role of oxidised low density lipoproteins in atherogenesis. Prog. Lipid Res. 31: 127-143.

112. Dröge, W. (1993) Cysteine and gluthathione deficiency in AIDS patients: a rationale for the treatment with N-acetyl-cysteine. Pharmacology 46: 61-65. 
113. Schneeberger, H., Schleibner, S., Schilling, M., Illner, W.D., Abendroth, D., Hancke, E., Janicke, U. and Land, W. (1990) Prevention of acute renal failure after kidney transplantation with rh-SOD; interim analysis of a double-bind placebo-controlled trial. Transp. Proceed. 22: 2224-2225.

114. Ganguly, P.K. (1991) Antioxidant therapy in congestive heart failure: is there any advantage? J. Inter. Med. 229: 205-208.

115. Hennekens, C.H., Buring, J.E. and Peto, R. (1994) Antioxidant vitamins - benefits not yet proved. New Engl. J. Med. 330: 1080-1081.

116. Flohé, L. (1988) Superoxide dismutase for therapeutic use: clinical experience, dead ends and hopes. Mol. Cell. Biochem. 84: 123-131.

117. Przyklenk, K. and Kloner, R.A. (1989) "Reperfusion injury" by oxygen-derived free radicals? Cir. Res. 64: 86-96.

118. Herbert, V. (1993) Dangers of iron and vitamin C supplements. J. Am. Diet. Assoc. 93: 526-527.

119. Turner, J.J.O., Rice-Evans, C., Davies, M.J. and Newma, E.S.R. (1991) The formation of free radicals by cardiac monocytes under oxidative stress and the effects of electrondonating drugs. Biochem. J. 277: 833-837.

120. Gutteridge, J.M.C., Quinlan, G.J., Swain, J. and Cox, J. (1994b) Ferrous ion formation by ferrioxamine prepared from aged desferrioxamine: a potential prooxidant property. Free Rad. Biol. Med. 16: 733-739.

121. Barinaga, M. (1991) Vitamin C gets a little respect. Science 254: 374-376.

122. Herbert, V. (1994) The antioxidant supplement myth. Am. J. Clin. Nutr. 60: 157-158. 